ROCZNIKI HUMANISTYYCZNE

Tom LXVII, zeszyt 6 - 2019

DOI: http://dx.doi.org/10.18290/rh.2019.67.6-11

TOMASZ ŻURAWLEW

\title{
ETYKA KOMUNIKACJI JAKO WYKŁAD UNIWERSYTECKI UWAGI O SPECYFICE I DYLEMATACH KSZTAŁCENIA
}

\section{SŁOWO WSTEPNE}

Współczesny dyskurs publiczny zdominowały dzielące Polaków konflikty społeczne. Są one źródłem wielu negatywnych zjawisk w sferze komunikacji - nierzadko skrajnie opresyjnych nadużyć języka, które degraduja go jako wartość samą w sobie, fundament całej kultury, ale nade wszystko degraduja osobowy wymiar człowieka i ludzkie wspólnoty. Fakty te skłaniają do refleksji i podejmowania działań na rzecz etycznej normalizacji czynów mownych użytkowników języka, m.in. poprzez budzenie potrzeby okazywania szacunku wobec godności wszystkich ludzi czy też namysł nad złymi skutkami agresji słownej, manipulacji, kłamstwa - takiego posługiwania się językiem, w wyniku którego redukowana jest ludzka podmiotowość.

Wspomniane działania możemy już zaobserwować w obszarze edukacji, który tworzy najwłaściwszą przestrzeń do upowszechniania wiedzy dotyczącej moralności komunikacyjnej. O ile jednak nauczanie tych zagadnień w szkołach podstawowych i średnich może odbywać się w ściśle określonych - de facto dalece ograniczonych podstawą programową ramach kształcenia polonistycznego ${ }^{1}$, o tyle na uczelniach wyższych treści te mogą formalnie stać się przedmiotem nauczania ustawicznego - na przykład tzw. wykładów ogólnouczelnianych, jeśli wykładowca stworzy program takich zajęć i zainteresuje

Dr TOMASZ ŻURAWLEW - Katedra Filologii Germańskiej, Wydział Humanistyczny Uniwersytetu Warmińsko-Mazurskiego w Olsztynie; adres do korespondencji: ul. Kurta Obitza 1, 10-725 Olsztyn; e-mail: tomasz.zurawlew@uwm.edu.pl

${ }^{1} \mathrm{O}$ wspomnianych ograniczeniach piszę więcej w pierwszym punkcie niniejszego artykułu. 
nim władze uczelni. Możliwość ich realizacji rodzi jednak sporo pytań, które wymagają podjęcia próby odpowiedzi, bo z jednej strony brakuje wypracowanych metod nauczania etyki komunikacji, z drugiej zaś - nie w pełni ugruntowana zdaje się sama koncepcja dydaktyczna, co sprawia, że trzeba rozstrzygnąć, czy wykładowca ma podążać w kierunku zrównania ważności celów poznawczych z celami o charakterze wychowawczym, czy też - ze względu na uniwersytecki wymiar kształcenia - bardziej powinien skupiać swoją uwagę na komponencie poznawczym wykładów, niż na kształtowaniu postaw komunikacyjnych ich odbiorców. I w jednym, i w drugim przypadku, a także wtedy, gdy cele wychowawcze miałyby w procesie kształcenia przeważać nad poznawczymi, kwestią bardzo ważną jest wybór właściwej drogi uzasadnienia charakterystycznych dla współczesnego dyskursu etyki komunikacji fundamentów wartościowania zjawisk komunikacyjnych ${ }^{2}$, bo jednym z celów takich wykładów winno być, jak się wydaje, wykształcenie u studentów umiejętności etycznej waloryzacji działań mownych. Wniosek taki nasuwa się przy analizie zaproponowanych przez Annę Cegiełę podstaw teoretycznych etyki komunikacji. Zdaniem badaczki dyscyplina ta winna zajmować się m.in. badaniem, opisem i oceną sposobów posługiwania się językiem w relacji do przyjętych przez społeczeństwo wartości oraz ustalaniem norm użycia słowa, które będą sprzyjać ochronie tych wartości ${ }^{3}$. A. Cegieła stwierdza ponadto, że etyka komunikacji ustala możliwości takiego kontaktu językowego, który jego uczestnikom zapewni poczucie bezpieczeństwa oraz równoprawne i pełnoprawne współdziałanie w danej wspólnocie komunikacyjnej ${ }^{4}$.

Inny, równie istotny problem, nad którym warto się zastanowić, związany jest z wymiarem odpowiedzialności wykładowcy za jego decyzje w ukazywaniu dróg poszukiwania prawdy o dobru komunikacyjnym i odróżniania go od zła oraz z kwestią ujawniania przez niego podczas prowadzenia wykładów własnej tożsamości moralnej. Jaką decyzję w tym zakresie powinien podjąć? Czy szanując wolność studentów ma on unikać jakiejkolwiek formy odkrywania przed nimi własnych doświadczeń i przekonań etycznych, czy też powinien zdobyć się na to, by swoje poglądy mniej lub bardziej ujawniać? A jeśli je ujawniać, to jak nie narazić się wtedy na zarzut braku obiektywizmu w prezentowaniu wiedzy dotyczącej moralnych i niemoralnych możliwości

\footnotetext{
${ }^{2}$ Więcej o tych fundamentach w punkcie drugim moich rozważań.

${ }^{3}$ A. CegIEŁA, Stowa i ludzie. Wprowadzenie do etyki słowa, Warszawa: Dom Wydawniczy Elipsa 2014, s. 9.

${ }^{4}$ Tamże, s. 20
} 
użycia słowa? I wreszcie: jak uczyć tych zagadnień, by nie stać się moralizującym gawędziarzem, a pozostać wykładowcą i po co ich uczyć?

Dylematy te są mi dobrze znane, ponieważ sam musiałem je rozstrzygać, gdy przed kilkoma laty zdecydowałem się prowadzić według autorskiego programu wykłady z etyki komunikacji na Uniwersytecie Warmińsko-Mazurskim. Gromadzona wiedza oraz zdobywane i pogłębiane z roku na rok doświadczenie pozwalają mi dziś przedstawić zarys ogólnodydaktycznych aspektów nauczania interesujących nas zagadnień i podjąć próbę odpowiedzi na przedstawione wyżej pytania. Mam świadomość, że nie rozwieją one wszystkich wątpliwości, jednakże z pewnością mogą wesprzeć osoby zainteresowane realizowaniem takich zajęć w przekazie wiedzy dotyczącej moralnych aspektów posługiwania się słowem, realnej, praktycznej i komunikatywnej eksplikacji wartości, o które opiera się moralne użycie języka, a także w kształtowaniu postaw komunikacyjnych studentów. Sądzę, że nauczanie na uniwersytecie zagadnień dotyczących moralności nie może ograniczać się tylko do samego przedstawienia bogactwa etosu, prezentacji różnorodnych systemów etycznych, czy dążenia do opanowania wiedzy o wspomnianych wartościach, bo zgubilibyśmy wtedy wielką okazję do wyeksponowania i umocnienia wychowawczej funkcji uniwersytetu.

\section{CO WARUNKUJE CELE KSZTAECENIA ETYKI KOMUNIKACJI JAKO PRZEDMIOTU AKADEMICKIEGO?}

Kształcenie etyki komunikacji związane jest z założeniami co najmniej kilku dyscyplin naukowych: filozofii moralnej, socjologii, psychologii społecznej, językoznawstwa aksjologicznego i pragmatycznego, a także ogólnej teorii nauczania i uczenia się, czyli dydaktyki. Filozofia moralności dostarcza nam wiedzy o systemach myślowych, z których można wyprowadzać zasady moralne ${ }^{5}$, socjologia pomaga określić, jakie czynniki społeczne wpływają na kształtowanie się ludzkich postaw moralnych i niemoralnych ${ }^{6}$, natomiast psychologia społeczna

\footnotetext{
${ }^{5}$ Por. A. Malitowska, Czym jest filozofia moralna?, „Filozofia Publiczna i Edukacja Demokratyczna" 1(2012), nr 1, s. 120-126 .

${ }^{6}$ Ważnym w literaturze światowej studium będącym przeglądem zagadnień socjologii moralności i podejmującym próbę ich systematyzacji jest praca M. OssowSKIEJ, Socjologia moralności. Zarys zagadnień, wyd. 4, Warszawa: Wydawnictwo Naukowe PWN 2018. Zob. także: J. MARIAŃSKI, Socjologia moralności, Lublin: Wydawnictwo KUL 2006 oraz Leksykon socjologii moralności, red. J. Mariański, Kraków: Nomos 2015.
} 
bada m.in. sposoby wpływania na postawy komunikacyjne ludzi oraz ich emocje $^{7}$. Z kolei badania aksjolingwistyczne zapoznają nas z dziedziną wyrażania wartości, m.in. kulturotwórczą funkcją języka wartości, którego używamy, starając się do nich ustosunkować ${ }^{8}$, a językoznawstwo pragmatyczne analizuje sposoby posługiwania się językiem przez ludzi - to właśnie na jego gruncie Herbert Paul Grice ustalił zasady kooperacji uczestników sytuacji komunikacyjnej, które przyczyniły się do powstania pierwszych założeń teorii etyki mowy ${ }^{9}$. Jak zostało to już wyżej podkreślone, edukacja etycznojęzykowa siłą rzeczy opiera się o założenia dydaktyki ogólnej ${ }^{10}$, która w zależności od obranych celów kształcenia pomaga ustalić metody nauczania interesujących nas zagadnień, tak by było ono skuteczne.

Źródeł warunkujących wspomniane cele jest zapewne wiele, ale sądzę, że trzeba tu wskazać - po pierwsze - na konieczność dbania przez uniwersytet o kulturę narodową, której ważnym elementem jest kultura słowa ${ }^{11}$, a po drugie - przypomnieć o misji polskiego szkolnictwa wyższego $\mathrm{w}$ ogóle ${ }^{12}$. W preambule najnowszej ustawy Prawo o szkolnictwie wyższym i nauce z dnia 20 lipca 2018 roku czytamy m.in., że „uczelnie oraz inne instytucje badawcze [...] współ-

${ }^{7}$ Por. M. KossowsKa, M. SEKerdeJ, Psychologia spoteczna: idea i eksperyment, w: W strone psychologii eksperymentalnej: w 110. rocznice zatożenia Pracowni Psychologii Doświadczalnej na Uniwersytecie Jagiellońskim, red. M. Kielar-Turska, Kraków: Wydawnictwo UJ 2016, s. 61-75. Zob. też B. WoJCISZKE, Psychologia społeczna, Warszawa: Wydawnictwo Naukowe Scholar 2012.

${ }^{8}$ Tym zagadnieniom poświęconych jest wiele prac badawczych Jadwigi PUZYNINY zebranych w zbiorze Wartości i wartościowanie w perspektywie językoznawstwa, Kraków: Wydawnictwo PAU 2013, a także powszechnie znana praca Autorki Język wartości, Warszawa: Wydawnictwo Naukowe PWN 1992.

${ }^{9}$ Popularyzatorką tych założeń stała się w Polsce wspomniana Jadwiga Puzynina. Zob. TEJżE, Problemy aksjologiczne $w$ jezykoznawstwie, „Poradnik Językowy” 1984, nr 9-10, s. 539-559. Badaczka oparła swoje rozważania dotyczące etycznych aspektów międzyludzkiej komunikacji o wspomnianą teorię zasad współdziałania językowego Grice’a, ale także o teorię aktów mowy J.L. Austina, którzy uzasadniali zależność komunikacji racjonalnej i skutecznej od szczerości nadawcy. Por. H.P. GRICE, Logika i konwersacja, przeł. J. Wajszczuk, „Przegląd Humanistyczny” 20(1977), nr 6, s. 89; J.L. Austin, Mówienie i poznawanie. Rozprawy i wykłady filozoficzne, przeł. B. Chwedeńczuk, Warszawa: Wydawnictwo Naukowe PWN 1993, s. 561-598.

${ }^{10}$ Zob. Cz. KuPISIEwICZ, Dydaktyka. Podręcznik akademicki, Kraków: Impuls 2012.

${ }^{11}$ Zob. J. PUZYNINA, Kultura stowa - ważny element kultury narodowej, Łask: Oficyna Wydawnicza Leksem 2011.

${ }^{12} \mathrm{O}$ randze funkcji wychowawczych uczelni wyższej przypomina w swoim tekście Kazimierz W. JASKOT - Funkcje szkoty wyższej jako instytucji edukacyjnej, w: Wprowadzenie do pedagogiki szkoły wyższej, red. K.W. Jaskot, Szczecin: Oficyna IN Plus 2006, s. 398-413. Inny ważny tekst w tej pracy zbiorowej: J. GNITECKI, Aksjologiczne podstawy stanowienia celów edukacyjnych szkoty wyższej, s. 32-51. 
kształtują standardy moralne obowiązujące w życiu publicznym", co według twórców ustawy „ma szczególne znaczenie dla państwa i narodu”13. Również w przedstawionym przez Instytut Badań nad Gospodarką Rynkową raporcie Misja, wizja i cele strategiczne szkolnictwa wyższego $w$ Polsce $w$ perspektywie $2020 \mathrm{roku}^{14}$ akcentuje się m.in. potrzebę realizacji zadań z obszaru etyki i podkreśla, że „uczelnie powinny służyć przełamywaniu barier etnicznych, budowaniu pozytywnych relacji między ludźmi różnych narodowości, religii i poglądów"15. Według autorów raportu, szkoła wyższa winna w realizowaniu swojej misji dbać o ,kształtowanie racjonalnych, etycznych i zaangażowanych postaw obywatelskich” oraz wyrabiać ,umiejętności współpracy opartej na wzajemnym zaufaniu"16. Cele kształcenia etyki komunikacji w środowisku akademickim warunkuje ponadto fakt, iż w podstawach programowych obowiązujących na etapach szkolnej edukacji przekaz wiedzy dotyczącej posługiwania się językiem w relacji do wartości moralnych został ograniczony do dalece niewystarczającego minimum. Uczniowie klas siódmych i ósmych szkoły podstawowej oraz uczniowie szkół średnich uczą się głównie zasad etykiety językowej i dowiadują się, czym jest perswazja, natomiast $\mathrm{z}$ obszaru etyki komunikacji rozpoznaja jedynie zjawisko manipulacji ${ }^{17}$. $\mathrm{Ci}$ z nich, którzy po zdaniu matury przekraczają progi uniwersytetu i decydują się na uczestnictwo w prowadzonych przeze mnie wykładach, często przyznają, że ich wiedza dotycząca aksjologicznych uwarunkowań procesu międzyludzkiej komunikacji ma charakter wyłącznie intuicyjny, i że rozeznania w zakresie wartości, o które działanie to się opiera, a także w zakre-

\footnotetext{
${ }^{13}$ Zob. http://konstytucjadlanauki.gov.pl/content/uploads/2018/08/kdn.pdf [dostęp: 03.02.2019].

${ }^{14}$ Raport ten jest wynikiem projektu realizowanego ze środków Unii Europejskiej $C z$ zowiek - najlepsza inwestycja. Zob. https://www.nauka.gov.pl/g2/oryginal/2013_05/9b9413 575c 0e968c236bbd1d1f0a64db.pdf [dostęp: 24.10.2018].

15 Tamże, s. 3.

16 Tamże.

17 Trzeba tu podkreślić, że etykieta językowa - inaczej mówiąc grzeczność językowa nie zależy bezpośrednio od norm moralnych. Często wiążemy ją po prostu z normami dobrego wychowania, które według Jadwigi Puzyniny „w odróżnieniu od norm moralnych nakazują różne formy zachowania po to, aby ktoś sądził, że ktoś drugi jest mu przyjazny, że go aprobuje itp., podczas gdy normy moralne nakazują rzeczywistą życzliwość wobec innych ludzi i ich aprobowanie”. J. Puzynina stwierdza dalej: „uprzejmość, grzeczność może być wyrazem szacunku i życzliwości, może też być wyrazem zakłamania; może nie wynikać z postawy «ku innemu», lecz z postawy «ku sobie», «ku własnym celom», celom osiąganym w sposób wyrachowany, oparty na znajomości psychicznych potrzeb partnerów interakcji”. Zob. J. PUZYNINA, A. PAJDZIŃSKA, Etyka słowa, w: O zagrożeniach i bogactwie polszczyzny, red. J. Miodek, Wrocław: Towarzystwo Przyjaciół Polonistyki Wrocławskiej 1996, s. 40-41. Por. też A. CEGIEŁA, Stowa i ludzie, s. 10-11.
} 
sie ochrony prawnej tych wartości brakuje im zupełnie. Ze względu na stan współczesnej kultury komunikacji, jakże w wielu sferach odległej od ideału społeczeństwa jako wspólnoty ${ }^{18}$, stwierdzić trzeba, że jest to wiedza bardzo przydatna, kształtująca osobowość studentów oraz niezbędne zdolności do odpowiedzialnej partycypacji w życiu społecznym i jego poszczególnych sferach, sprzyjająca kształtowaniu postawy dialogu opartej na wzajemnym szacunku czy wreszcie rozwijająca władzę sądzenia, umiejętność kwalifikacji moralnej określonych czynów - zresztą nie tylko mownych.

Biorąc pod uwagę przedstawione wyżej ogólne uwarunkowania celów kształcenia etyki komunikacji w szkole wyższej, możemy dojść do wniosku, że w nauczaniu tym da się wyróżnić dwa komplementarne wobec siebie wymiary: rzeczowy i osobowościowy. Wymiar rzeczowy wiąże się m.in. z poznawaniem świata wartości, a ściślej: objaśnianiem tych, które mogą realizować się w komunikacji - m.in. godności człowieka, jego suwerenności, równoprawności, prawdy rozumianej jako przeciwieństwo kłamstwa, rozważaniem treści stanowionego prawa oraz innych ważnych społecznie dokumentów oficjalnych $^{19}$, dzięki którym wspomniane wartości podlegają ochronie, czy wreszcie analizowaniem w relacji do tych wartości wybranych przez wykładowcę sytuacji komunikacyjnych. Natomiast wymiar osobowościowy związany jest z nabywaniem przez studentów sprawności sprzyjających kształtowaniu własnego sumienia, tak by pozostawało ono w łączności z wolnością i prawdą, rozwojem świadomości, że czyn mowny (i nie tylko mowny) nieuchronnie ujawnia osobę oraz że drugi człowiek, z którym podejmuje się rozmowę, jest podmiotem mającym swoją godność, a także z rozwijaniem zdolności do odkrywania prawdy o dobru i rozważania kwestii moralnych, czyli de facto rozstrzygania tzw. konfliktów wartości. Zdaje się, że niejeden taki konflikt w zakresie użycia słowa można w ludzkim doświadczeniu wyodrębnić: skłamać, przemilczeć czy powiedzieć prawdę osobie, której stan zdrowia wskazuje na nieuchronność śmierci?; decydować się na tzw. uczciwą perswazję słowną w kontaktach handlowych, czy kierować się, zgodnie z za-

\footnotetext{
${ }^{18}$ Problem ten rozważa J. Puzynina w tekście: Kultura popularna a kultura wysoka - dziś, w: Relacje między kulturq wysoka i popularna w literaturze, języku i edukacji, red. B. Myrdzik, M. Karwatowska, Lublin: Wydawnictwo UMCS. Zob. TEJŻE, Kultura stowa - ważny element kultury narodowej, s. 55-66. Zob. także A. CEGIEŁA, Stowa niebezpieczne i niepożadane w przestrzeni spotecznej. Etyka słowa a poprawność polityczna, „Poradnik Językowy” 2013, $\mathrm{nr} 1$, s. 57-70 oraz TEJŻE, O retoryce pogardy $i$ wykluczenia $w$ polskim dyskursie publicznym, „Poradnik Językowy” 2012, nr 9, s. 14-25.

${ }^{19}$ Wspominam o nich szerzej w punkcie trzecim tej pracy.
} 
leceniami przełożonych, wyłącznie zyskiem i zatajać fakty, które mogłyby wpłynąć niekorzystnie na sprzedaż danych towarów i świadczenie usług?

Sądzę, że wskazane wyżej wymiary kształcenia warunkują się nawzajem ze względu na sam przedmiot edukacji, który z natury rzeczy dąży do usprawniania - w tym wypadku studentów - w praktycznym łączeniu wiedzy o wartościach z postawami komunikacyjnymi oraz uczy jednoczesnego posługiwania się intelektem i wolą. Wydaje się więc, że na poziomie dydaktyki akademickiej czymś nienaturalnym byłoby minimalizowanie aspektu wychowawczego takich wykładów, czy ograniczanie się wykładowcy tylko do eksplikacji istoty wspomnianych wyżej wartości, rozważania sensu języka sądów moralnych, analizy tego, jak w przeszłości i teraźniejszości ludzie uzasadniali i uzasadniają uznawane przez siebie wartości. Z perspektywy pedagogiki szkoły wyższej jako dyscypliny teoretycznej i praktycznej uważam, że nauczanie tych zagadnień poza wychowaniem do cnoty jest niemożliwe do zaakceptowania $^{20}$. W praktyce prowadzenia wykładów z etyki komunikacji wydaje się więc najbardziej uzasadnione zrównanie ważności celów wychowawczych z celami poznawczymi.

\section{UWAGI O FUNDAMENTACH ANTROPOLOGICZNYCH KSZTAŁCENIA ETYKI KOMUNIKACJI I SPECYFICZNEJ ROLI WYKŁADOWCY}

Proces stanowienia celów kształcenia etyki komunikacji jest z natury rzeczy uwarunkowany aksjologicznie i wiąże się z wymiarem szczególnej odpowiedzialności wykładowcy za nauczanie tych zagadnień - tym bardziej że odpowiedzialność ta zakłada istnienie wartości, a ściślej: uznanie tych wartości i działanie ze względu na nie. Odpowiedzialność wykładowcy warunkuje ponadto opisany w poprzednim rozdziale osobowościowy wymiar kształcenia, czyli zamierzone wspieranie rozwoju osobowego studentów w celu pogłębienia ich komunikacyjnej dojrzałości. Powstaje więc pytanie, na jakich fundamentach antropologicznych tę dojrzałość budować?

Stwierdzić trzeba, że moralność na pewnym stopniu ogólności może mieć charakter uniwersalny. Wiadomo jednak, że w historii myśli etycznej znajdziemy różne jej uzasadnienia - od utylitarystycznych po personalistyczne,

\footnotetext{
${ }^{20} \mathrm{O}$ społecznych aspektach kształcenia w szkole wyższej pisze S. PALKA, Charakterystyka pedagogiki szkoty wyższej jako dyscypliny teoretycznej i praktycznej, w: Wprowadzenie do pedagogiki, s. 12-30. Autor podkreśla, że działania edukacyjne uczelni wyższej mają służyć m.in. kształtowaniu osobowości studentów i wspomaganiu rozwoju tej osobowości.
} 
przy czym te ostatnie właśnie są dla teorii etyki komunikacji najbardziej konstytutywne, m.in. ze względu na ich spójność z jej celem globalnym ochroną ludzkiej podmiotowości w użyciu języka ${ }^{21}$.

$\mathrm{W}$ poszukiwaniu modelu etycznej komunikacji wspomniana na początku Anna Cegieła przyjmuje charakterystyczny dla tych uzasadnień paradygmat filozofii dialogu za ,jedyny, w którym można rozpatrywać kwestie etyczne, a zwłaszcza problemy etycznego użycia języka, oraz pojęcie osoby jako podstawowe dla tych rozważań" ${ }^{22}$. Ale również w publikacjach innych autorów współtworzących polski dyskurs etyki komunikacji ujawnia się eksplikacja działania komunikacyjnego w ścisłej relacji do osobowego bytu człowieka jako źródła i fundamentu powinności, a nie jego funkcjonalistycznych czy utylitarystycznych uwarunkowań, które stanowią przedmiot rozważań spoza personologii ${ }^{23}$.

Wróćmy jednak do ustaleń A. Cegieły, która czerpiąc z dokonań takich filozofów dialogu, jak m.in. Martin Buber, Karl Barth, Emmanuel Levinas czy Józef Tischner, konstatuje:

Niezależnie od tego, jaką perspektywę wybierzemy i jaki język posłuży do opisu zasad rozmowy z Drugim, trzeba stwierdzić, że Drugi jest osobą, podmiotem i, mówiąc słowami Emmanuela Levinasa, jestem mu dłużny (winien) dbałość o zachowanie jego podmiotowości oraz ochronę jego godności ${ }^{24}$.

\footnotetext{
${ }^{21}$ Mam tu na myśli uzasadnienia wywodzone z: (1) personalizmu przedmiotowego, w którym godność ludzka opisywana jest jako wartość ujawniająca się w doświadczeniu zewnętrznym (doświadczeniu osoby na tle świata); (2) personalizmu podmiotowego, w którym godność ludzka wyjaśniana jest w relacji do doświadczenia wewnętrznego (doświadczenia osoby w sobie samym zarówno poprzez spełnienie czynu, jak również poprzez stwierdzenie prawdy w akcie asercji); (3) personalizmu międzypodmiotowego, w którym doświadczenie osoby eksplikowane jest w relacji do innej osoby. Te trzy rodzaje personalizmu uważam za konstytutywne dla fundamentów antropologicznych teorii etyki komunikacji. Opisane w pracy Kazimierza Krajewskiego dwa inne rodzaje personalizmu, tj. personalizm teistyczny (osoba jako teofania, miejsce objawienia się osobowego Absolutu) oraz personalizm chrześcijański (relacja osoby ludzkiej do osoby Chrystusa w związku z doświadczeniem winy) nie znajdują zastosowania w teorii etyki komunikacji ze względu na stricte teologiczne uwarunkowania. Więcej o wymienionych rodzajach personalizmu etycznego w pracy autora: Personalizm etyczny w lubelskiej szkole filozoficznej, w: Etyka, cz. 1: Koncepcje etyki, red. S. Janeczek, A. Starościc, Lublin: Wydawnictwo KUL 2016, s. 229-261.

22 A. CegIEŁA, Stowa i ludzie, s. 50.

${ }^{23}$ Mam tu na myśli publikacje zebrane w tomie Etyka stowa. Wybór opracowań I, red. J. Bartmiński, S. Niebrzegowska-Bartmińska, M. Nowosad-Bakalarczyk i J. Puzynina, Lublin: Wydawnictwo UMCS 2017.

${ }^{24}$ A. CegieŁA, Stowa i ludzie, s. 50.
} 
Badaczka słusznie zauważa, że etyczne posługiwanie się językiem to takie, w którym szanuje się osobowy wymiar człowieka, złożoność i wielowymiarowość jego natury, a także ludzką niepowtarzalność, tożsamość, odrębność, autonomiczność - suwerennośćc ${ }^{25}$. Wydaje się więc, że dla formułowania celów kształcenia interesujących nas zagadnień najbardziej przekonujące fundamenty odnajdziemy w personalistycznej koncepcji etyki, której aksjomaty - spójne z zaproponowanymi przez A. Cegiełę teoretycznymi podstawami moralności komunikacyjnej - dobrze przysłużą się do ustalania kryteriów etycznej waloryzacji czynów mownych, co w moim przekonaniu winno być jednym z najważniejszych zadań wykładowcy. Jego opowiedzenie się za tą koncepcją uzasadnia ponadto fakt, iż w kluczowych dokumentach oficjalnych, które powstały w wyniku negocjacji międzynarodowych gremiów, i o które teoria etyki komunikacji opiera swoje twierdzenia, czyli w Powszechnej Deklaracji Praw Człowieka z roku 1948, preambule Karty Praw Podstawowych Unii Europejskiej z roku 2007 oraz preambule Konstytucji Rzeczypospolitej Polskiej z roku 1997, wyraźnie mówi się o człowieku jako osobie. Sądzę jednak, że kontrproduktywnie zadziała ten wykładowca, który nie przedstawi studentom istoty innych niż personalistyczna koncepcji etycznych i swojego wyboru w dyskusji z nimi nie uzasadni. Wydaje się, że uzasadnienie to najlepiej jest zacząć od pytania „kim jest człowiek?”, bo przecież człowiek właśnie w każdym procesie komunikacyjnym obecny jest jako jego twórca, sprawca i uczestnik. Według założeń koncepcji personalistycznej jest on fundamentem tego procesu i - co ważne - proces ten ujawnia go jako osobę, jako samorządny podmiot, centrum świadomego, wolnego i przez prawdę związanego czynu, który w przypadku rozważań etycznojęzykowych rozumiemy jako czyn mowny ${ }^{26}$. Założenia koncepcji personalizmu etycznego - najlepiej, gdyby były objaśniane sprawdzoną metodą dyskusji dydaktycznej pozwalają więc w sposób najbardziej pełny ujmować relacje komunikacyjne z perspektywy podmiotowości człowieka i, co równie istotne, umożliwiają najgłębszy wgląd w wartości, o które opiera się moralne użycie języka.

Wspomniana metoda dyskusji dydaktycznej zakłada, że wykładowca nie pełni jedynie roli kogoś, kto tę dyskusję nadzoruje. Jego zadaniem jest pomóc „rodzić się” prawdzie o dobru komunikacyjnym, nie ograniczając jednak wolności studentów, tzn. tak prowadzić etyczny dyskurs, by studenci czuli się

\footnotetext{
25 Tamże, s. 53.

${ }^{26}$ Por. M. DrożDż, Osoba i media. Personalistyczny paradygmat etyki mediów, Tarnów: Biblos 2005, s. 46-47.
} 
związani z wnioskami, do których sami dojdą drogą racjonalnej dedukcji. A dojdą do nich wtedy, gdy będą uczestnikami dialogu z wykładowcą, a nie słuchaczami jego monologu. Studenci muszą wiedzieć, z kim rozmawiają, komu przedstawiają swoje przemyślenia, czyli de facto znać osobiste poglądy wykładowcy dotyczące omawianej podczas wykładów etycznej problematyki. Wobec tego możemy dojść do wniosku, że dyskusja dydaktyczna jako jedna z metod kształcenia zagadnień moralności komunikacyjnej warunkuje potrzebę ujawnienia przez wykładowcę jego własnych przekonań etycznych, co zreszta według mojego doświadczenia korzystnie wpływa na proces budowania właściwej, tzn. opartej na zaufaniu relacji między prowadzącym wykład a studentami. Można tu przywołać charakterystyczną dla takich wykładów sytuację, w której wykładowca rozważa problematykę ludzkiej wolności, a dyskusję tę prowadzi m.in. w celu próby ujęcia tej konstytutywnej dla moralnego posługiwania się słowem wartości w ramy definicyjne. W takiej sytuacji dydaktycznej z natury rzeczy założyć trzeba, że poglądy na temat wolności będą wypowiadane w ogniu wzajemnej krytyki, i że wykładowca w finale dyskusji zostanie spytany przez studentów, które z przekonań są najbliższe jego rozumieniu tego pojęcia. Czy może on sobie pozwolić wtedy na brak otwartości? Sądzę, że nie. Podobnego zdania jest Katarzyna Olbrycht, która, rozważając problem zaangażowania światopoglądowego nauczyciela etyki w procesie dydaktycznym, stwierdza:

Obiektywizm prezentowania wiedzy [etycznej - T.Ż.] nie może być mylony z brakiem poglądów i postaw, szczególnie gdy dotyczy roli pedagoga, której treść zawsze - czy to $\mathrm{w}$ teorii czy w praktyce - wyznaczają $\mathrm{w}$ pierwszym rzędzie koncepcja człowieka i jego rozwoju oraz stosunek do prawdy (niezależnie od stopnia, w jakim pedagog jest tego świadomy) ${ }^{27}$.

Słowa badaczki pomagają zrozumieć, że kwestię ujawniania przez dydaktyka jego przekonań etycznych winniśmy rozpatrywać - ze względu na właściwy wykładom etyki komunikacji problemowy charakter - jako naturalną kolej rzeczy, jednak przede wszystkim jako drogę do poszukiwania przez studenta własnej odrębności osobowościowej i światopoglądowej i, co chyba najważniejsze, weryfikowania jego przekonań w konfrontacji z poglądami, wiedzą i doświadczeniem otwartego na ludzką poszczególność, uczciwego wykładowcy. Wydaje się, że problematyki moralnego i niemoralnego posługiwania się

${ }^{27}$ K. OlBRycht, Odpowiedzialność pedagoga w nauczaniu etyki, w: Etyka w szkole, red. Z. Sareła, Warszawa: Wydawnictwo ATK 1997, s. 78. 
językiem nie da się analizować bez światopoglądowego zaangażowania osoby prowadzącej takie wykłady. Ważne jest jednak, aby nauczyciel potrafił wsłuchiwać się w racje studentów - zwłaszcza wtedy, gdy prezentują oni odrębne poglądy, stwarzał możliwości ich wyrażania i je szanował, bo taka postawa $\mathrm{z}$ jednej strony uchroni go przed przejęciem funkcji moralizatora, $\mathrm{z}$ drugiej zaś - będzie spójna z jednym z celów, który jego wykładom przyświeca uwrażliwianiem użytkowników języka na potrzebę okazywania szacunku w działaniu komunikacyjnym. Jednakże nie mniejszą rolę w dążeniu do osiągnięcia wspomnianego celu odegraja wybrane przez niego metody przekazu wartości.

\section{UWAGI O METODACH KSZTAECENIA}

Jak już zostało podkreślone, podstawę etyki komunikacji jako dyscypliny badawczej i refleksji humanistycznej stanowią wartości moralne, spośród których najbardziej konstytutywne dla etycznego opisu działań językowych są godność i wolność ludzka, równoprawność, prawda - rozumiana jako przeciwieństwo kłamstwa, a także międzyludzka solidarność. Przedstawione wyżej wymiary kształcenia - rzeczowy i osobowościowy - wynikają z istnienia i uznania tych wartości. Sposób ich przekazu a także wiedzy szczegółowej dotyczącej z jednej strony istoty niepożądanych zjawisk językowych oraz ich skutków, m.in. kłamstwa, manipulacji, wszelkich aktów agresji słownej, komunikacji redukującej ludzką podmiotowość i podlegającej restrykcjom (dominacji, mobbingu), z drugiej zaś - pożądanych form użycia słowa respektujących zasadę inkluzji, równouprawnienia, braku przymusu, rzetelnego argumentowania ${ }^{28}$, winien $\mathrm{w}$ moim przekonaniu poruszać zarówno intelekt, jak i - w tej samej mierze - uczucia studentów. Trzeba więc podczas wykładów stworzyć możliwość przeżycia wartości - nierzadko w relacji do przeżycia antywartości, by szkodliwość tych ostatnich mogła zostać jak najpełniej uświadomiona. Decyzję o wyborze określonych metod kształcenia powinien zatem poprzedzać namysł nad możliwością odwołania się w nich nie tylko do aktywności poznawczej, ale również do sfery emocjonalnej studentów.

Wyróżniam wobec powyższego dwa komplementarne wobec siebie rodzaje przekazu wartości mogących realizować się w komunikacji - intelektualny i emocjonalny. Spośród metod, które umożliwią łączenie rozumowego pozna-

\footnotetext{
${ }^{28}$ Więcej o tych zasadach w pracy A. CEGIEŁY, Stowa i ludzie, s. 42-43.
} 
nia wartości z jednoczesnym ich przeżyciem, wskazać trzeba szczególnie na: (1) dyskusję dydaktyczną (już wspomnianą), (2) metodę biograficzną - m.in. z wykorzystaniem edukacji filmowej, (3) pracę z tekstem w celu etycznojęzykowej analizy jego treści, (4) kształcenie literackie z wykorzystaniem konwersacyjnego wymiaru tekstów artystycznych. Oczywiście wykładowca z natury rzeczy musi posługiwać się powszechnie znaną metodą podającą - wtedy jednak, ze względu na wspomnianą konieczność dążenia do internalizacji wartości opartej na ich przeżyciu, winien integrować ją z metodą, która przeżycie to będzie zakładać. Zresztą, integrowanie metod to praktyka dość powszechna i nierzadko konieczna - warunkowana m.in. specyfiką założonych celów kształcenia.

O dyskusji dydaktycznej była już mowa, warto jednak dodać, że jako forma zorganizowanej wymiany myśli i poglądów uczestników wykładu winna być w przemyślany sposób dobrana do celu, który wykładowca chce osiągnąć. Metoda ta jest pewnego rodzaju środkiem oddziaływania na przekonania oraz postawy i jako taka prowadzi drogą wspólnego namysłu nad określonym problemem do jego rozwiązania ${ }^{29}$. Stwierdzić trzeba, że dyskusja dydaktyczna pozwala zaznajomić studentów m.in. z bardzo złożoną i skomplikowaną problematyką aksjosfery - np. z różnymi koncepcjami godności człowieka, która stanowi pojęcie o niewyraźnych konturach znaczeniowych, czego powodem może być wieloaspektowe pojmowanie tej wartości w historii myśli europejskiej ${ }^{30}$. Nauczający, poznawczo uwarunkowany tok dyskusji pozwoli ujawnić źródła rzeczonej wieloaspektowości w różnorodnym naświetleniu problemu, a zadaniem prowadzącego dyskurs będzie wsparcie studentów w dotarciu do prawdy o ludzkiej godności poprzez dodatkowe uruchomienie sfery przeżyciowej, np. odwołanie się do zapisanych na kartach historii opresyjnych prób degradacji podmiotowości człowieka. Można na przykład pokazać zdjęcie żydowskiej matki prowadzonej wzdłuż drutów kolczastych wraz z kilkorgiem jej dzieci do komory gazowej w Auschwitz ${ }^{31}$, albo wyświetlić przejmujący fragment filmu pt. Generat Nil (reż. R. Bugajski), w którym

\footnotetext{
${ }^{29}$ Por. L. ZARZECKI, Wybrane problemy dydaktyki ogólnej, Jelenia Góra: Kolegium Karkonoskie. Państwowa Wyższa Szkoła Zawodowa 2008, s. 83.

30 Por. A. KoJder, Godność, w: Fundamenty dobrego spoteczeństwa. Wartości, red. M. Bogunia-Borowska, Kraków: Znak 2015, s. 46-64 (tu s. 46). Autor wyróżnia i opisuje w swoim tekście cztery odmienne koncepcje godności, które nadal są w użyciu i wywołują ożywione dyskusje znawców przedmiotu.

${ }^{31}$ Mam na myśli fotografię z niemieckiego Bundesarchiv (dostępną również w Internecie) Kobieta z dziećmi $w$ drodze do komory gazowej $w$ Auschwitz-Birkenau, Bild 183-74237004/CC-BY-SA 3.0.
} 
niewinny dowódca Kedywu Armii Krajowej stoi na zapadni tuż przed wykonaniem wyroku kary śmierci. I jeden, i drugi obraz, a także każdy inny ukazujący podobny dramat ludzkiego losu, uświadomi siłą przekazu, że odebranie człowiekowi życia nie ma nic wspólnego z odebraniem mu osobowej godności. W tak ujętym planie działania dydaktycznego przewagę w prowadzonym dyskursie ma szansę zyskać ta koncepcja godności człowieka, w której wartość tę warunkuje sam fakt bycia osobą, a nie zależność od prawa, religii czy też określonych funkcjonalistycznych założeń. Dyskusja dydaktyczna ma jednak jeszcze jedną ważną zaletę - ważną w tym sensie, że jest to zaleta spójna z głoszonym przez etykę komunikacji wymogiem szacunku wobec godności każdego człowieka. Otóż metoda ta wdraża studentów, pod okiem wykładowcy, do niełatwej sztuki i kultury dyskutowania, uczy ich dystansu do pozamerytorycznych dygresji i postaw zacietrzewienia ${ }^{32}$.

Za sprawdzoną metodę dążenia do internalizacji fundamentalnych dla etycznego porozumiewania się wartości uważam nauczanie odwołujące się bezpośrednio do postaw ludzi, których jako wspólnota komunikacyjna bardzo cenimy ze względu na skuteczne praktykowanie przez nich określonych idei. Nie chodzi przy tym o przyswajanie konkretnych faktów i zdarzeń z życia danych osób, lecz o dostrzeganie w ich postawach komunikacyjnych pożądanych motywów działania oraz przeżycie emocji związanych z osobowym wymiarem tego działania. Poprzez stosowanie metody biograficznej - najlepiej byłoby, gdyby mogła być ona oparta na elementach edukacji filmowej - dana jest studentom możliwość skonfrontowania ich systemu wartości z systemem wartości innych i poszerzenia w tak zaplanowany sposób ich własnych horyzontów aksjologicznych ${ }^{33}$. Korzystający z tej metody wykładowca winien jednak tak dobrać materiał biograficzny i kierować na jego podstawie wnioskowaniem, by miało ono charakter konstytutywny dla namysłu o etycznym użyciu słowa oraz skutkach nieetycznego posługiwania się nim.

Przykłady produkcji filmowych, które dostarczą podstaw do takich rozważań, można by mnożyć. W moim przekonaniu przydatny będzie film pt. Dzieci Ireny Sendlerowej (reż. J.K. Harrison), ukazujący problem niesionego m.in. przez język antysemityzmu oraz sprzeciwiające się mu postawy głównej bohaterki, w których ogólny szacunek do życia ludzkiego miał charakter wielopostaciowy i objawiał się m.in. poprzez dające się spostrzec $\mathrm{w}$ działaniu

\footnotetext{
32 Por. Cz. KuPISIEwICZ, Dydaktyka. Podręcznik akademicki, s. 138-139.

${ }^{33}$ Por. J. JezIORSKA, Metoda biograficzna w nauczaniu etyki, „Studia Philosophiae Christianae" 40(2004), nr 1, s. 193-195.
} 
słowem poszanowanie ludzkiej wolności ${ }^{34}$, odwagę powiedzenia nieprawdy w sytuacji, gdy prawdę w celach ludobójczych wymuszano siłą ${ }^{35}$, czy odwrotnie - odwagę powiedzenia prawdy, kiedy od niszczycielskich działań trzeba było uchronić przynajmniej niewinne dzieci ${ }^{36}$.

Innym materiałem audiowizualnym, przydatnym $\mathrm{w}$ realizacji metody biograficznej, który z jednej strony skutecznie wesprze wykładowcę w przekazywaniu wiedzy o wartościach konstytuujących działania językowe ludzi, z drugiej zaś będzie dobrym źródłem namysłu nad sposobem, w jaki można prowadzić życzliwy dialog, jest cykl wywiadów telewizyjnych z prof. Leszkiem Kołakowskim pt. Rozmowy z mistrzem. Rozmówcy poruszają w nim ważne społecznie zagadnienia, np. istotną dla teorii etyki komunikacji problematykę praw człowieka, kwestię sprawiedliwości społecznej, warunkowanego m.in. przez kulturę słowa patriotyzmu, a także rozpatrują istotę międzyludzkiej przyjaźni.

Ponieważ realizacja metody biograficznej może, jak podkreśla J. Jeziorska, polegać na rozważaniu odpowiadających problematyce przedmiotu losów postaci fikcyjnych ${ }^{37}$, warto podczas wykładu posłużyć się fikcją filmową, jednakże wyłącznie taką, która przedstawia sytuacje spójne z doświadczanymi w rzeczywistości. Wspomnę tu o filmie fabularnym pt. Pręgi (reż. M. Piekorz), ukazującym akty agresji ojca wobec jego syna oraz jej dalekosiężne i skrajnie negatywne skutki. Obraz ten jest niewątpliwie dobrą okazją do dyskusji ze studentami o możliwościach opresji, które kryje w sobie mowa ludzka, kiedy staje się narzędziem w ustach człowieka o neurotycznej, silnie zaburzonej osobowości. Film jest zazwyczaj głęboko przeżywany, dlatego

\footnotetext{
${ }^{34}$ Między innymi mam tu na myśli tę scenę filmu, w której Irena Sendlerowa podczas spotkania $\mathrm{z}$ pracownicami wydziału opieki prowadzi z nimi dialog w celu ustalenia, która $\mathrm{z}$ nich chciałaby wesprzeć ją w zorganizowaniu pomocy Żydom w warszawskim getcie. Warto zwrócić w tej scenie uwagę na sposób prowadzenia tego dialogu - z góry szanujący decyzje tych jej koleżanek, które nie będą chciały wesprzeć tego działania.

${ }^{35}$ Można tu wskazać na kilka fragmentów filmu. Pouczająca jest scena, w której oficerowie gestapo wchodzą do mieszkania Ireny Sendlerowej, dokonują rewizji oraz groźbą dopominają się od bohaterki przyznania się do tego, że pomaga Żydom - ta jednak zaprzecza. Inną ważną sceną jest ukazanie Ireny Sendlerowej w sytuacji bezwzględnych tortur, podczas których niezłomnie twierdzi, że nie uczestniczy w organizowaniu pomocy Żydom, i że nie wie nic o ludziach udzielających takiej pomocy.

${ }^{36}$ Chodzi m.in. o scenę, w której główna bohaterka podejmuje dialog z członkami żydowskich rodzin, próbując ich przekonać, że zagłada Żydów zbliża się nieuchronnie, i że jednym ze sposobów pomniejszenia jej zasięgu jest uchronienie przed nią przynajmniej dzieci - przekazanie ich za pośrednictwem Ireny polskim rodzinom i innym ośrodkom opieki.

${ }^{37}$ Por. J. JeZIORSKA, Metoda biograficzna w nauczaniu etyki, s. 193.
} 
sprawdza się jako skuteczny materiał do rozważań problematyki przemocy werbalnej i niewerbalnej, takich niemoralnych przejawów użycia języka jak szantaż, etykietowanie czy szyderstwo.

Etyka komunikacji rozumiana jako refleksja badawcza otwiera perspektywę moralnego namysłu nad określonymi faktami językowymi, dlatego kształcenie związanych z nią zagadnień powinno opierać się również na etycznojęzykowej analizie tekstu, przy czym podkreślić trzeba, że przy stosowaniu takiej metody chodzi o opis i ocenę moralną treści tekstów zarówno pisanych, jak i mówionych, odpowiednio dobranych przez wykładowcę w planowaniu działania dydaktycznego. Analiza tekstu pisanego, zaczerpniętego z prasy czy Internetu, ma te zalety, że nie tylko umożliwia namysł nad przejawami niemoralności komunikacyjnej, wyrażonymi wprost, lecz również pozwala rozważać te jej sygnały, które dają się spostrzec dopiero przy wnikliwszej analizie tzw. konotacji tekstowych. Z kolei etycznojęzykowa analiza tekstów mówionych zakłada ich audiowizualizację, w wyniku której dane zachowania mowne można rozważać w dużo szerszej perspektywie, uwzględniającej istotę znaków pozawerbalnych, które mogą dostarczać informacji m.in. o intencjach rozmówców. Dla analizy określonych postaw komunikacyjnych ma to duże znaczenie, ponieważ uświadamia, że moralne lub niemoralne mogą być towarzyszące mowie różnorakie gesty.

W metodzie opartej na zarysowanej tu analizie tekstu kryteria opisu i oceny danych postaw językowych wynikają z uznania tych wszystkich wartości, o których była już mowa, czyli - ogólnie mówiąc - ustalane są one na podstawie ontycznego faktu, że człowiek jest osobą. Etyczna waloryzacja działań komunikacyjnych zakłada więc pytanie o to, czy i w jaki sposób działania te spełniają zasadę zachowania osobowego wymiaru człowieka, tzn. czy nie czynią go mniej człowiekiem, w jakim stopniu uwzględniają one złożoność i wielowymiarowość jego natury, czy przyznaje się mu prawo do własnych przekonań, a także ich zmiany bez narażania się na utratę poczucia bezpieczeństwa, i wreszcie, czy w działaniach tych mówi się prawdę czy kłamie opis danej postawy komunikacyjnej według kryterium uczciwości jest jednak możliwy tylko wtedy, gdy znamy prawdę, np. w wyniku tego, że kłamstwo wyszło na jaw.

Tekstów będących nośnikami uczciwej perswazji lub manipulowania, szacunku lub lekceważenia, życzliwości lub agresji, prawdy lub kłamstwa, jest w naszej codziennej rzeczywistości bardzo wiele i od wykładowcy, a ściślej - celów, które sobie stawia, będzie zależał ich dobór. Źródłem przejawiania się warunkowanej dobrem lub złem mowy ludzkiej są niewątpliwie mnożące się dziś nowe media, ale także w tradycyjnej prasie, radio i telewizji odnaj- 
dziemy wypowiedzi, które posłużą kształtowaniu u studentów umiejętności etycznej waloryzacji użyć języka.

Przykładem wypowiedzi pisemnej, której skutki prawne mogły być przecież przewidziane, zanim została ogłoszona drukiem, jest tekst red. Jerzego Urbana pt. Obwoźne sado-maso, pozostawiający do dziś duży niesmak, mimo iż od ogłoszenia go drukiem minęło wiele lat ${ }^{38}$. Autor w roku 2002, przed ostatnim już przyjazdem do Polski Jana Pawła II, publikuje w swoim tygodniku tekst, w którym głowa państwa watykańskiego i Kościoła powszechnego została potraktowana jak zużyty przedmiot - stary „kapeć”, który „mamrocze o miłości bliźniego". Publikacja ta jest z jednej strony przykładem skrajnej depersonifikacji człowieka, ale $\mathrm{z}$ drugiej strony wykładowca i studenci w opresyjnym i wulgarnym rejestrze mowy Redaktora dostrzega dalece nieudaną próbę budowania fałszywego obrazu Papieża.

Innym przykładem redukcji osobowego wymiaru człowieka w użyciu języka jest zarejestrowany w Internecie przebieg rozmowy redaktorów J. Wojewódzkiego i M. Figurskiego, która miała miejsce na antenie Radia ESKA ${ }^{39}$. Prowadzący audycję posłużyli się mową dyskryminującą, stygmatyzującą i ekstremalnie poniżającą ukraińskie kobiety, podsuwając nawet możliwość użycia wobec nich przemocy seksualnej. Na proceder zareagowało ukraińskie MSZ, w wyniku czego śledztwo w tej sprawie wszczęła prokuratura - podobnie zreszta jak w wyżej wspomnianym przypadku red. Urbana. Obie sprawy skończyły się wyciągnięciem odpowiedzialności karnej wobec pozwanych, co w tym kontekście uznać trzeba za właściwą okazję do rozważenia podczas wykładów zapisów chroniącego ludzką godność prawa ${ }^{40}$.

W tym miejscu chciałbym wyraźnie podkreślić, że zarówno nowe, jak i stare media umożliwiają w tej samej mierze dostęp do tekstów, za pomocą których wykładowca etyki komunikacji ukaże studentom sposoby pisania czy też mówienia służące wyrażaniu postaw pozytywnych, sprzyjających poczuciu wspólnotowości i bezpieczeństwa.

\footnotetext{
${ }^{38}$ Zob. J. URBAn, Obwoźne sado-maso, „Nie” 2002, nr 33, s. 2.

${ }^{39}$ Zob. https://www.youtube.com/watch?v=yq5SdiBux7Q [dostęp: 24.10.2018]. Etycznojęzykową analizę wypowiedzi redaktorów przeprowadza w swojej książce A. CEGIEŁA, Słowa i ludzie, s. 127-128.

${ }^{40}$ Regulacje prawne, które chronią ludzką godność przed aktami agresji słownej, szczegółowo omawia M. ANDRUSZKIEWICZ, Problemy etyki stowa w państwie prawa, w: Filozoficzne i teoretyczne zagadnienia demokratycznego państwa prawa, red. M. Andruszkiewicz, A. Breczko, S. Oliwniak, Białystok: Temida 2 2015, s. 15-27.
} 
Z punktu widzenia potrzeby internalizacji wartości, o które opiera się moralne użycie języka, metodą skuteczną może być również kształcenie literackie realizowane $\mathrm{w}$ formie refleksji nad wybranymi przez wykładowcę treściami prozy lub poezji. Chodzi tu jednak głównie o utwory lub ich fragmenty mające charakter konwersacyjny, tzn. takie, w których „trwają” rozmowy. Dlatego nie tekst z metaforycznie bogatym opisem otaczającej człowieka rzeczywistości miałby tu być przedmiotem refleksji wykładowcy i jego studentów, lecz utwór, w którym autor zaprojektował międzyludzki dialog z językowymi przejawami zapośredniczonego przez język szacunku, okazanego w życzliwym słowie poczucia braterstwa, czy z sygnałami poszukującej zgody otwartości na drugiego człowieka. Oczywiście trzeba liczyć się z tym, że sygnały te będą ukryte w presupozycjach semantycznych, dlatego konieczny może się okazać wysiłek ich poszukiwania, ale to właśnie przesądza o poznawczym charakterze zajęć - rozpoznawaniu złożonej struktury znaczeniowej określonych słów, które mogą być moralne lub niemoralne zarówno w wymiarze pojęciowym, jak i konotacyjnym. Dobór utworów będzie zależał od czytelniczych doświadczeń wykładowcy i jego własnych predylekcji literackich, chciałbym tu jednak wspomnieć o tzw. konwersacyjnych wierszach Wisławy Szymborskiej - fenomenie powszechnie znanym wśród czytelników poezji noblistki, który możemy rozpatrywać nie tylko z punktu widzenia uwarunkowań literaturoznawczych, ale również w perspektywie teorii etyki mowy, czego dowodzę w innym tekście ${ }^{41}$.

Powróćmy jeszcze na chwilę do klasycznej metody podającej, czyli tzw. wykładu, który, jak podkreśla Czesław Kupisiewicz, „nie tyle oddziałuje na wyobraźnię i uczucia oraz pobudza myślenie konkretno-obrazowe, co raczej aktywizuje umysł, a zwłaszcza myślenie hipotetyczno-dedukcyjne" ${ }^{\text {, }}$. Cz. Kupisiewicz wskazuje na czynniki, które powinny warunkować metodę wykładu i wymienia: przejrzystą logiczną strukturę, żywy język, racjonalne rozmieszczenie momentów syntetyzujących oraz wielostronne naświetlenie głównego wątku merytorycznego. Autor stwierdza jednak, że wskaźniki recepcji treści eksponowanych przy stosowaniu metody podającej nie są na ogół wysokie i wahają się w granicach od 20 do $50 \%$. Dane te wskazują na to, co zostało już wspomniane - konieczność integrowania metody podającej z wyżej opisanymi, tak by wykładowca mógł jak najlepiej zrealizować cele wynikające

${ }^{41}$ Zob. T. ŻURAWLEW, Konwersacyjny wiersz Szymborskiej w świetle teorii etyki komunikacji, „Poradnik Językowy” 7(2019), s. 72-83.

${ }^{42}$ Cz. Kupisiewicz, Dydaktyka. Podręcznik akademicki, s. 136. 
z przedstawionych i scharakteryzowanych w punkcie pierwszym tego artykułu wymiarów kształcenia etyki komunikacji. Nauczanie tą metodą zakłada przekaz treści mających głównie teoretyczny charakter. Źródłem, z którego można je czerpać, jest wielokrotnie przywoływana tu praca Anny Cegieły Stowa i ludzie. Wprowadzenie do etyki stowa.

\section{UWAGI KOŃCOWE}

Problematyka kształcenia etyki komunikacji jako wykładu uniwersyteckiego została tu przedstawiona w ogólnym zarysie, według moich własnych doświadczeń dydaktycznych, ale również na podstawie teorii moralności komunikacyjnej oraz teorii kształcenia ogólnego.

Poczynione ustalenia pozwalają zrozumieć, że zdobyta podczas wykładów wiedza może znacząco warunkować jakość ludzkich działań komunikacyjnych, jeśli znajdzie ona swoje zastosowanie w praktyce. Jest to wiedza o ludzkiej godności, wolności, równoprawności, braterstwie, prawdzie (w sensie, w jakim była o niej mowa), a więc o tych wszystkich wartościach, które, jeśli będą realizowane w działaniu komunikacyjnym, moga zwiększyć jego skuteczność i sprawić, że realniejsza stanie się współpraca na rzecz dobra wspólnego. Wiedzę tę winni posiadać studenci po ukończeniu kursu, ale dopełniać ją musi również znajomość stanowionego prawa oraz treści wymienionych w mojej pracy dokumentów oficjalnych, dzięki którym wspomniane wartości podlegają ochronie.

Wykłady z etyki komunikacji wiążą się również z wykształceniem u studentów określonych sprawności. Składają się na nie zdolność do etycznej oceny własnych działań mownych, podejmowania aksjologicznej refleksji nad sposobem, w jaki komunikują się inni, i - co chyba najważniejsze - umiejętność posługiwania się językiem ze świadomością, iż jest on środkiem budowania relacji z drugim człowiekiem opartej na wzajemnym szacunku. Umiejętność ta winna wynikać z osobowościowego wymiaru kształcenia. Zakłada on świadome dążenie przez studentów do osiągnięcia dojrzałości komunikacyjnej, a więc takiego posługiwania się słowem, które - jak stwierdza J. Puzynina - jest charakterystyczne dla ludzi

dojrzałych pod względem duchowym, emocjonalnym, pod względem rozumienia wagi racjonalności, moralności, estetyki i siły woli. Ludzi traktujących w sposób przemyślany podział na dobro i zło, rozumiejących wagę empatii, życzliwości, otwartości wobec inności. Ludzi dobrych, mądrych, uczciwych, wewnętrznie 
silnych, odważnych, odpowiedzialnych w realizowaniu podjętych zadań, w ich planowaniu, organizowaniu i w działaniu na ich rzecz - ogólnie odpowiedzialnych za to, co mówią i co czynią 43 .

Trzeba przyznać, że na wykładowcy spoczywa niełatwe zadanie, choć z drugiej strony może być ono pasjonujące ${ }^{44}$. Trud, jaki musi zadać sobie nauczyciel, wynika m.in. ze wspomnianej interdyscyplinarności zagadnień, które mają charakter aksjo- i pragmalingwistyczny, filozoficzny, socjologiczny, a nawet psychologiczny i jako takie właśnie wyznaczają dydaktykowi kierunek aktywności poznawczej. Włożony przez niego wysiłek poznania oraz podjęta odpowiedzialność za ukazywanie dróg poszukiwania prawdy o dobru mogą poskutkować odwzajemnionym przez studentów zaufaniem oraz ich radością z faktu, że w coraz bardziej anonimowej społeczności, w jakiej wszyscy żyjemy, odkryli autorytet, o który mogą się oprzeć.

\section{BIBLIOGRAFIA}

ANDRUSZKIEwICZ M.: Problemy etyki słowa w państwie prawa, w: Filozoficzne i teoretyczne zagadnienia demokratycznego państwa prawa, red. M. Andruszkiewicz, A. Breczko, S. Oliwniak, Białystok: Temida 2 2015, s. 15-27.

Austin J.L.: Mówienie i poznawanie. Rozprawy i wykłady filozoficzne, przeł. B. Chwedeńczuk, Warszawa: Wydawnictwo Naukowe PWN 1993, s. 561-598.

CegieŁA A.: O retoryce pogardy i wykluczenia w polskim dyskursie publicznym, „Poradnik Językowy" 2012, nr 9, s. 14-25.

CegieŁa A.: Słowa i ludzie. Wprowadzenie do etyki słowa, Warszawa: Dom Wydawniczy Elipsa 2014.

CegieŁA A.: Słowa niebezpieczne i niepożądane w przestrzeni społecznej. Etyka słowa a poprawność polityczna, „Poradnik Językowy” 2013, nr 1, s. 57-70.

DROŻDŻ M.: Osoba i media. Personalistyczny paradygmat etyki mediów, Tarnów: Biblos 2005.

Etyka słowa. Wybór opracowań I, red. J. Bartmiński, S. Niebrzegowska-Bartmińska, M. Nowosad-Bakalarczyk, J. Puzynina, Lublin: Wydawnictwo UMCS 2017.

GNITECKI J.: Aksjologiczne podstawy stanowienia celów edukacyjnych szkoły wyższej, w: Wprowadzenie do pedagogiki szkoły wyższej, red. K.W. Jaskot, Szczecin: Oficyna IN Plus 2006, s. 32-51.

43 J. PUZYNINA, Co oznacza dojrzała komunikacja? Zob.: https://www.kon gresobywatel ski.pl/idee-dla-polski-kategoria/co-oznacza-dojrzala-komunikacja/ [dostęp: 24.10.2018].

${ }^{44}$ Zadanie to jest przedmiotem refleksji J. Puzyniny w udzielonym mi wywiadzie. Zob. Świętość - moralność - język (z Profesor Jadwiga Puzynina rozmawia Tomasz Żurawlew), w: Święci i świętość w języku, literaturze i kulturze, red. H. Leleń, T. Żurawlew, Kraków: Universitas 2018, s. 407-412, tu: 409-410. 
GRICE H.P.: Logika i konwersacja, przeł. J. Wajszczuk, „Przegląd Humanistyczny” 20(1977), nr 6, s. 59-99.

JASKOT K.W.: Funkcje szkoły wyższej jako instytucji edukacyjnej, w: Wprowadzenie do pedagogiki szkoły wyższej, red. K.W. Jaskot, Szczecin: Oficyna IN Plus 2006, s. 398-413.

JEZIORSKA J.: Metoda biograficzna w nauczaniu etyki, „Studia Philosophiae Christianae” 40(2004), nr 1, s. 193-211.

KoJDER A.: Godność, w: Fundamenty dobrego społeczeństwa. Wartości, red. M. BoguniaBorowska, Kraków: Znak 2015, s. 46-64.

KossowsKa M., SeKerdeJ M.: Psychologia społeczna: idea i eksperyment, w: W stronę psychologii eksperymentalnej: w 110. rocznicę założenia Pracowni Psychologii Doświadczalnej na Uniwersytecie Jagiellońskim, red. M. Kielar-Turska, Kraków: Wydawnictwo Uniwersytetu Jagiellońskiego 2016, s. 61-75.

KRAJEWSKI K.: Personalizm etyczny w lubelskiej szkole filozoficznej, w: Etyka, cz. 1: Koncepcje etyki, red. S. Janeczek, A. Starościc, Lublin: Wydawnictwo KUL 2016, s. 229-261.

KuPISIEwICZ Cz.: Dydaktyka. Podręcznik akademicki, Kraków: Impuls 2012.

Leksykon socjologii moralności, red. J. Mariański, Kraków: Nomos 2015.

Malitowska A.: Czym jest filozofia moralna?, „Filozofia Publiczna i Edukacja Demokratyczna" 1(2012), nr 1, s. 120-126.

MARIAŃSKI J.: Socjologia moralności, Lublin: Wydawnictwo KUL 2006.

OLBRYCHT K.: Odpowiedzialność pedagoga w nauczaniu etyki, w: Etyka w szkole, red. Z. Sareła, Warszawa: Wydawnictwo ATK 1997, s. 71-79.

OssowsKa M.: Socjologia moralności. Zarys zagadnień, wyd. 4, Warszawa: Wydawnictwo Naukowe PWN 2018.

PALKA S.: Charakterystyka pedagogiki szkoły wyższej jako dyscypliny teoretycznej i praktycznej, w: Wprowadzenie do pedagogiki szkoły wyższej, red. K.W. Jaskot, Szczecin: Oficyna IN Plus 2006, s. 12-30.

PUZYNINA J., PAJDZIŃSKA A.: Etyka słowa, w: O zagrożeniach i bogactwie polszczyzny, red. J. Miodek, Wrocław: Towarzystwo Przyjaciół Polonistyki Wrocławskiej 1996, s. 35-45.

PUZYNINA J.: Język wartości, Warszawa: Wydawnictwo Naukowe PWN 1992.

PUZYNINA J.: Kultura słowa - ważny element kultury narodowej, Łask: Oficyna Wydawnicza Leksem 2011.

PUZYNINA J.: Kultura popularna a kultura wysoka - dziś, w: TEJŻE, Kultura słowa - ważny element kultury narodowej, Łask: Oficyna Wydawnicza Leksem 2011, s. 55-66.

PUZYNINA J.: Problemy aksjologiczne w językoznawstwie, „Poradnik Językowy” 1984, nr 9-10, S. 539-559.

PUZYNINA J.: Wartości i wartościowanie w perspektywie językoznawstwa, Kraków: Wydawnictwo PAU 2013.

URBAN J.: Obwoźne sado-maso, „Nie” 2002, nr 33, s. 2.

WoJCiszKe B.: Psychologia społeczna, Warszawa: Wydawnictwo Naukowe Scholar 2012.

ZARZECKI L.: Wybrane problemy dydaktyki ogólnej, Jelenia Góra: Kolegium Karkonoskie. Państwowa Wyższa Szkoła Zawodowa 2008

ŻURAWLEW T.: Konwersacyjny wiersz Szymborskiej w świetle teorii etyki komunikacji, „Poradnik Językowy" 7(2019), s. 72-83.

ŻURAWLEW T.: Świętość - moralność - język (z Profesor Jadwigą Puzyniną rozmawia Tomasz Żurawlew), w: Święci i świętość w języku, literaturze i kulturze, red. H. Leleń, T. Żurawlew, Kraków: Universitas 2018, s. 407-412. 


\section{NETOGRAFIA}

https://www.nauka.gov.pl/g2/oryginal/2013_05/9b9413575c0e968c236bbd1d1f0a64db.pdf http://www.etykaslowa.edu.pl/

https://www.youtube.com/watch?v=yq5SdiBux7Q

https://www.kongresobywatelski.pl/idee-dla-polski-kategoria/co-oznacza-dojrzala-komunikacja/ http://konstytucjadlanauki.gov.pl/content/uploads/2018/08/kdn.pdf

\section{ETYKA KOMUNIKACJI JAKO WYKŁAD UNIWERSYTECKI UWAGI O SPECYFICE I DYLEMATACH KSZTAŁCENIA}

\section{S t r e s z c z e n i e}

Celem pracy jest przedstawienie i opisanie ogólnodydaktycznych aspektów kształcenia etyki komunikacji na poziomie akademickim. Autor dąży do tego celu, opierając swoje rozważania o teorię moralności komunikacyjnej oraz teorię kształcenia ogólnego. Określa specyfikę nauczania zagadnień etycznojęzykowych, wyodrębnia dwa jego wymiary: rzeczowy i osobowościowy, z których można wyprowadzać cele edukacyjne, wskazuje również na dwa sposoby przekazu wartości: intelektualny i emocjonalny. Autor ustala ponadto, że zarówno dydaktyczny, jak i wychowawczy charakter zadań wykładowcy etyki komunikacji cechuje ten sam stopień ważności oraz opisuje najistotniejsze, jego zdaniem, metody edukacyjne. Odnosi się również do kilku typowych sytuacji dydaktycznych, próbując na ich tle wyjaśnić złożoność określonych dylematów kształcenia, a także wskazać możliwe drogi ich rozstrzygania.

Słowa kluczowe: etyka komunikacji; cele i metody kształcenia zagadnień etycznojęzykowych; wartości, o które opiera się moralne użycie języka; koncepcja personalizmu etycznego.

\section{ETHICS OF COMMUNICATION AS A UNIVERSITY LECTURE COMMENTS ON THE SPECIFICITY AND DILEMMAS OF EDUCATION}

$$
\text { S u m m a r y }
$$

The aim of this work is to present and describe the general didactic aspects of education in the field of ethics of communication at the academic level. The author pursues this goal by anchoring his deliberations in the theory of communicative morality and the theory of general education. He defines the specificity of teaching ethical language issues and distinguishes its two dimensions: material and personal. These dimensions serve as sources for educational goals. The author also points to two ways of conveying values: intellectual and emotional. In addition, he states that both the didactic and pedagogical character of the tasks of a lecturer of communication ethics is characterized by the same degree of importance. He describes educational methods which he personally finds the most significant. The author refers as well to some typical didactic situations, and using them as a background, he tries to explain the complexity of specific educational dilemmas, and then he indicates possible ways of resolving them.

Key words: ethics of communication; goals and methods of education of ethical linguistic issues; values on which the moral use of language is based; the concept of ethical personalism. 